\title{
The Effect of Plasmapheresis on Post-Thymectomy Ocular Dysfunction
}

\author{
C.W. OLANOW, A.D. ROSES, and J.W. FAY
}

SUMMARY: Five myasthenia gravis patients with post-thymectomy residual ocular signs were treated with plasmapheresis. Despite a significant reduction in $A C h R$ antibody titer, there was no clinical improvement. Subsequently, there was a dramatic response to prednisone. The $A C h R$ antibody titer did not correlate with the clinicalstate of the individual patient. It is suggested that plasmapheresis may operate by removing a thymic factor and that prednisone acts by a different mechanism.

RESSUME: Nous avons traité cinq patients souffrant de myasthénie grave, mais avec signes oculaires résiduels après thymectomie, avec plasmaphérèse. Malgré une diminution significative du titre des anticorps au récepteur cholinergique ( $A C h$ $R)$, il n'y eut aucune amélioration clinique. Par la suite il y eut réponse dramatique à la prednisone. Le titre $A C h R$ ne correspond en rien à l'état clinique d'un patien donné. Il est suggéré que la plasmaphérèse agit en enlevant le facteur thymique et que la prednisone agit par un mécanisme différent.

From the Department of Medicine (Division of Neurology). Howard Hughes Medical Institute: Department of Medicine (Division of HematologyOncology). Duke University Medical Center. Durham. North Carolina

Reprint requests to: Dr. C.W. Olanow, Department of Medicine (Neurology). Duke University Medical Center. Durham. North Carolina. USA. 27710.

\section{INTRODUCTION}

Phasmapheresis has recently been employed in the treatment of myasthenia gravis (Behan et al., 1979; Dau et al., 1977; Pinching et al., 1976). It has generally been reserved for more severely affected patients who have failed to respond to other forms of therapy. Improvement is usually temporary and therefore it has been combined with either steroids and/or immunosuppressive agents in the attempt to obtain long term benefit.

Circulating acetylcholine receptor ( $A C h R$ ) antibodies have been found in the serum of $90 \%$ patients with myasthenia gravis (Lindstrom et al., 1976). They have been implicated in the pathogenesis of this disorder by passive transfer studies (Toyka et al., 1977), in vitro degradation of receptors in myotube tissue culture (Kao \& Drachman, 1977), and by a myasthenic syndrome induced by monoclonal antibody directed to the AChR receptor (Lennon \& Lambert, 1980).

Plasmapheresis is presumed to operate by removing a circulating humoral factor which is essential to the pathogenesis of myasthenia gravis (Newsom-Davis et al., 1978). Clinical improvement has been reported to be associated with a reduction in the $\mathrm{ACh}$ antibody titer suggesting this may be the specific circulating factor (Newsom-Davis, et al., 1979).

In our clinic, we have used plasmapheresis to prepare myasthenic patients for thymectomy. Anticholinesterase agents and steroids are avoided. If patients have already been started on medication prior to referral, attempts are made to discontinue them during plasmapheresis (Wechsler \& Olanow, In Press). Thymectomy is then performed by a sternal splitting approach. We attempt a total thymectomy by removing all mediastinal fat and searching carefully for any ectopic foci of thymic tissue (Wechsler \& Olanow, 1980). Post-operative medications are not employed, if possible. Clinical follow-up studies with serial AChR antibody levels have suggested that a thymic factor may be essential in the pathogenesis of myasthenia gravis (Olanow \& Roses, in press (c)). We have failed to demonstrate a direct correlation between the antibody titer and the clinical course of individual patients (Roses et al., In Press). Furthermore, patients who have undergone thymectomy with no other therapy have shown dramatic improvement, but continue to maintain elevated $A C h R$ antibody levels (Olanow et al. (a), In Press; Olanow et al. (b), In Press).

While the majority of our patients became asymptomatic following early thymectomy, some had residual ocular dysfunction. Prior to the institution of any other medical therapy, plasmapheresis was performed in 5 patients with residual ocular dysfunction to determine whether a reduction in $A C h R$ antibody titer in this population would improve these signs. We report the failure of plasmapheresis to influence residual post-thymectomy dysfunction in any of these patients despite significant AChR antibody reduction.

\section{MATERIAL AND METHODS}

Five myasthenia gravis patients who had undergone previous thymectomy were entered into the study (Table I). Diagnosis was based on clinical, electrical, pharmacological and serological criteria. Thymectomy was performed within 6 months of onset of symptoms. Each patient improved but had some persistent ocular dysfunction. Each was responsive to edrophonium chloride and was receiving no medication. 
TABLE I

Characteristics of Patients with

Post-Thymectomy Ocular Dysfunction

\begin{tabular}{ccccc}
\hline Patients & Age & $\begin{array}{c}\text { Pre-Op } \\
\text { Grade }\end{array}$ & $\begin{array}{c}\text { Post-Op } \\
\text { Grade }\end{array}$ & $\begin{array}{c}\text { Interval } \\
\text { Thymectomy- } \\
\text { Plasmapherisis }\end{array}$ \\
\hline A & 44 & Ila & I & 13 mos. \\
B & 63 & Ila & I & 30 mos. \\
C & 32 & Ila & I & 26 mos. \\
D & 58 & Ila & I & 5 mos. \\
E & 61 & Ilc & I & 31 mos. \\
\hline
\end{tabular}

*Graded according to Osserman (1972).

Plasmapheresis, using an IBM Cell Separator, was carried out 5 to 31 months following thymectomy. Three to 4 liters of plasma were removed per exchange and replaced isovolemically with $2-3 \%$ albumin in Ringer's lactate. Four to 11 procedures were performed on each patient. ACh R antibody titers were serially measured using a radioimmunoassay technique with human antigen (McAdams \& Roses, 1980). AChR antibody titers were elevated in each case ranging from 0.194 to 14.8 $\mathrm{nM}(0.1 \mathrm{nM}$ is diagnostic and greater than $1 \mathrm{nM}$ is highly abnormal in our laboratory).

Following plasmapheresis, no medications were introduced during the subsequent 3 weeks. Thereafter, prednisone therapy in gradually increasing doses was begun. Ocular dysfunction was quantitated using a clinical grading system illustrated in Table II.

RESULTS

The results are summarized in Table
III. Plasmapheresis was well tolerated by all patients. A significant but temporary reduction in $A C h R$ antibody titer was obtained in all patients ranging from 58 to $100 \%$. No significant improvement in ocular function was demonstrated in any patient despite a drop in antibody titer which exceeded $90 \%$ in 3 of the patients.

Prednisone therapy, by contrast, resulted in striking clinical improvement in all patients. Three of the 5 patients became asymptomatic and had normal eye examinations. Improvement occurred within 2 to 8 weeks following the institution of therapy. A comparison of the effect of plasmapheresis and prednisone on post-thymectomy residual ocular dysfunction is illustrated in Figure I. Figure II represents the serial AChR antibody levels and the clinical response of a typical patient treated with plasmapheresis and subsequently prednisone. Clinical improvement was not associated with a reduction in the
TABLE II

for Grading Ocular Dysfunction

Test

Ptosis - Left Eye

Ptosis - Right Eye

External Ocular Muscle Function

Orbicularis Ocular Function

TABLE III

Results of Treatment with Plasmapheresis and Steroids

\begin{tabular}{|c|c|c|c|c|c|c|c|}
\hline Patients & $\begin{array}{l}\text { No. Runs } \\
\text { of P.P. }\end{array}$ & $\begin{array}{c}\text { Pre P.P. } \\
\text { ACH R AB } \\
\text { Titre (nM) }\end{array}$ & $\begin{array}{c}\% \text { Drop } \\
\text { IN ACH R } \\
\text { AB Titre }\end{array}$ & $\begin{array}{c}\text { Max. } \\
\text { Steroid } \\
\text { Dose }\end{array}$ & $\begin{array}{c}\text { Pre P.P. } \\
\text { Grade }\end{array}$ & $\begin{array}{c}\text { Post P.P. } \\
\text { Clinical } \\
\text { Grade }^{\star}\end{array}$ & $\begin{array}{l}\text { Post } \\
\text { Steroid } \\
\text { Clinical } \\
\text { Grade }^{\star}\end{array}$ \\
\hline 1 & 4 & 0.43 & $80 \%$ & $30 / 30$ & (6) & (6) & (1) \\
\hline 11 & 5 & 1.87 & $92 \%$ & $30 / 15$ & (4) & (4) & (0) \\
\hline III & 5 & 0.27 & $100 \%$ & $30 / 00$ & (5) & (5) & (0) \\
\hline IV & 4 & 0.20 & $100 \%$ & $20 / 20$ & (5) & (5) & (0) \\
\hline v & 11 & 14.80 & $58 \%$ & $40 / 00$ & (5) & (5) & (2) \\
\hline
\end{tabular}

*Grading of ocular dysfunction ats described in Table II 
COMPARATIVE EFFECT OF PLASMAPHERESIS AND PREDNISONE ON RESIDUAL POST-THYMECTOMY OCULAR FEATURES

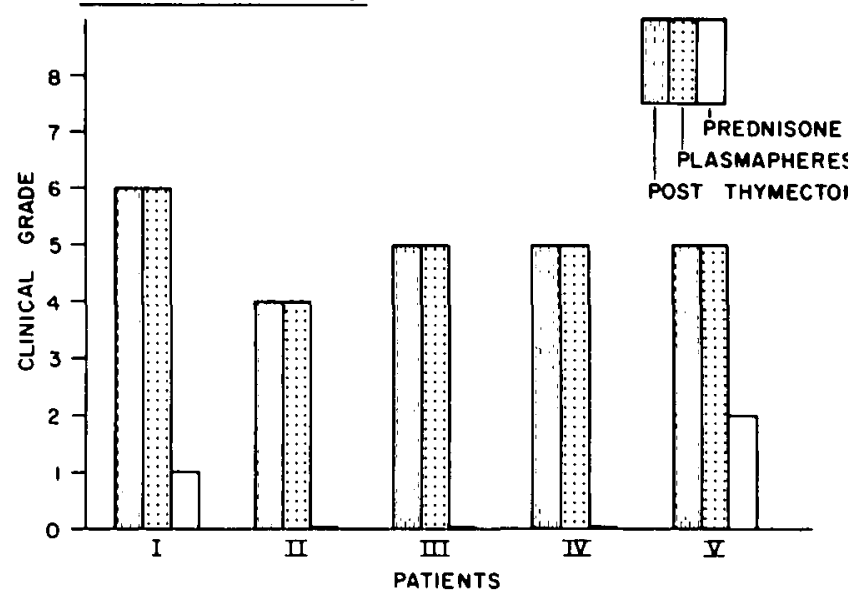

Figure I - A comparison of the effects of plasmapheresis and prednisone on residual post-thymectomy ocular dysfunction. Ocular dysfunction is scored according to Table II.

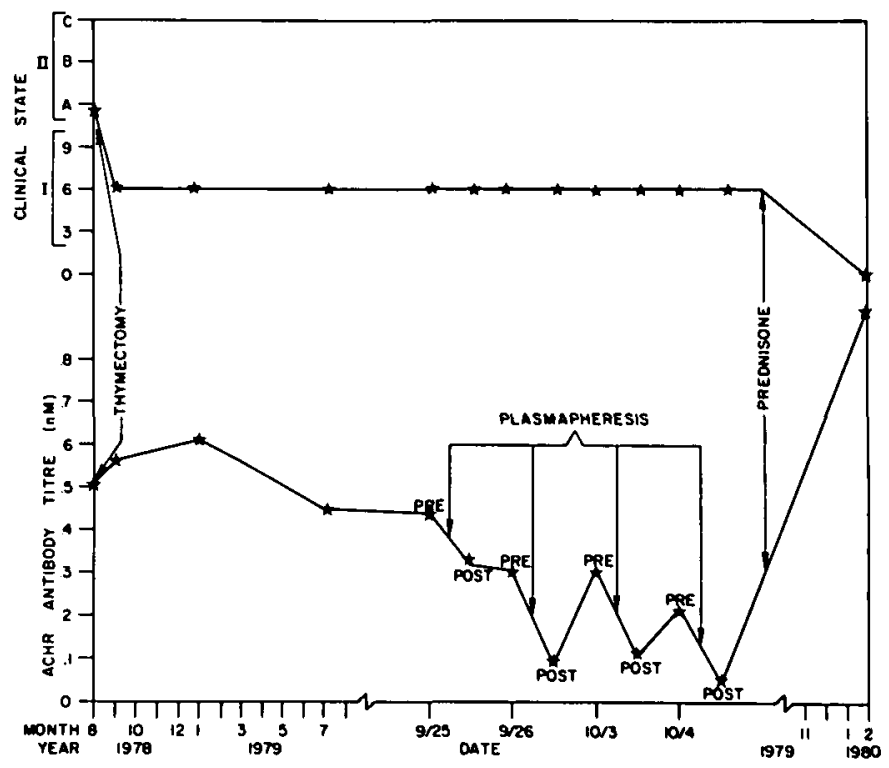

Figure 2 - Effects of thymectomy, plasma pheresis and prednisone on the clinical course and AChR antibody levels of a representative patient. The clinical state is classified according to Osserman (1972). Ocular dysfunction (Grade I) is further subdivided according to a scoring system outlined in Table II. an evaluation of the role of plasmapheresis, it seems likely that improvement is due to plasmapheresis, since when medications are employed alone benefit is relatively delayed (NewsomDavis, et al., 1979). Many of the reported patients have also had thymectomies. They are, however, severely affected with myasthenia gravis and it is possible that the thymic influence was not totally eradicated, due to incomplete or delayed thymectomy. This might occur for the severity and progression of symptoms despite thymectomy and the subsequent beneficial effect of plasmapheresis.

It is questioned whether plasmapheresis acts by removal of the AChR antibody. Despite a dramatic reduction in AChR antibody titer induced by plasmapheresis, no clinical improvement was detected in our patients. The possibility that there are subsets of antibodies to the AChR which are not currently detected, seems unlikely in view of the dramatic response to plasmapheresis we observe when preparing our patients for thymectomy. The possibility that the antibody may bind more tightly to the ACh R of eye muscles and thus be less responsive to plasmapheresis is consi- dered. More prolonged plasmapheresis theoretically may have led to some benefit. This also seems unlikely, however, since no such delay is noted in the response of the ocular features of myasthenia gravis to plasmapheresis prior to thymectomy.

The failure of a plasmapheresis induced reduction in the AChR antibody titer to improve postthymectomy ocular dysfunction suggests that plasmapheresis may operate by the removal of other factor(s), independent of or in addition to the AChR antibody. The beneficial effect of plasmapheresis prior to thymectomy suggests that these factor(s) may be of thymic origin. It is known that thymic-derived T-lymphocytes can regulate the intensity of virtually all immune reactions (Reinhez \& Schlossman, 1980). This study casts further doubt on the AChR antibody being the sole causative basis of myasthenia gravis and suggests that factors of thymic origin are of critical importance in the development of clinical symptoms. The mechanism by which prednisone operates is unknown but appears to be different than plasmapheresis.

\section{ACKNOWLEDGEMENTS}

This study was supported in part by a Clinical Research Grant from the Muscular Dystrophy Association and by NIH Grant CA 26401 and was presented in part to the $X V$ th Canadian Congress of Neurological Sciences, Ottawa. 1980.

\section{REFERENCES}

BEHAN, P.O., SHAKIR, R.A., SIMPSON, J.A., BURNETT, A.K., ALLAN, T.L., and HAASE. G. (1979). Plasma exchange combined with immunosuppressive therapy in myasthenia gravis. Lancet 2:438-440.

DAU, P.C., LINDSTROM, J.M., CASSEL, C.K., DENNYS, E.H., SHEV, E.V., and SPITLER, L.E. (1977). Plasmapheresis and immunosuppressive drug therapy in myasthenia gravis. N. Eng. J. Med. 297:11341140 .

KAO, I., and DRACHMAN, D.B. (1977). Myasthenic immunoglobulin accelerates acetylcholine receptor degradation. Science 196:527-529.

LENNON, V.A., and LAMBERT, E.H. (1980). Myasthenia gravis induced by monoclonal antibodies to acetylcholine receptors. Nature 285:238-240.

LINDSTROM, J.M., SEYBOLD, M.E., LENNON, V.A., WHITTINGHAM, S., and DUANE, V.D. (1976). Antibody to acetylcholine receptor in myasthenia gravis. Neurology 26:1054-1059.

MCADAMS、M., and ROSES、A.D. (1980). Comparison of antigen sources for acetylcholine receptor antibody assays in myasthenia gravis. Ann. Neurol. 8:61-66. 
NEWSOM-DAVIS, J., PINCHING, A.J., VINCENT, A., and WILSON, S.G. (1978). Function of circulating antibody to acetylcholine receptor in myasthenia gravis: investigation by plasma exchange. Neurology 28:266-272.

NEWSOM-DAVIS, J., VINCENT, A., WILSON, S.G.. and WARD, C.D. (1979). Long term effects of repeated plasma exchange in myasthenia gravis. Lancet I (issue 8114):464468.

OLANOW, C.W., LANE, R.J.M., and ROSES, A.D. (In Press). (a) Thymectomy in late onset myasthenia gravis. Neurology.

OLANOW. C.W.. LANE. R.J.M., and ROSES, A.D. (In Press). (b) Acetycholine receptor antibody levels following thymectomy in myasthenia gravis. Ann. N.Y. Acad. Sci.
OLANOW, C.W., and ROSES, A.D. (In Press) (c). The role of the thymus gland in myasthenia gravis; - a hypothesis.

OSSERMAN, K.E., and GENKINS, G. (1972). Studies in myasthenia gravis: Review of a twenty year experience in over 1200 patients. Mt. Sinai J. Med. 38:497-537.

PINCHING. A.J., PETERS, D.K., and NEWSOM-DAVIS, J. (1976). Remission of myasthenia gravis following plasma exchange. Lancet 2:1373-1376.

REINHEZ, E.L., and SCHLOSSMAN, S.F. (1980). Regulation of the immune responseinducer and suppressor T-lymphocyte subsets in human beings. N. Eng. J. Med. 303:370-373.

ROSES, A.D., OLANOW, C.W., MCADAMS,
M.W., and I.ANE. R.J.M. (IN PRESS). There is no direct correlation between the serum anti-acetylcholine receptor antibody levels and the clinical status of individual patients with myasthenia gravis. Neurology.

TOYKA, K.V., DRACHMAN, D.B., GRIFIN, D.E., PESTRON, K.A., WINKEL.STEIN, J.A., FISCHBECK, K.H., and KAO, I. (1977). Myasthenia gravis: study of humoral immune mechanisms by passive transfer to mice. N. Eng. J. Med. 296:125-131.

WECHSLER, A.W., and OLANOW, C.W. (IN PRESS). Myasthenia gravis. In D. Sabiston (Ed.) Christopher Textbook of Surgery.

WECHSLER, A.W., and OLANOW, C.W. (1980). Surgical therapy of myasthenia gravis. In W. Wolfe (Ed.) Surg. Clin. N.A. 60:931-945. 